\title{
PEMBAJAKAN KARYA LAGU MELALUI APLIKASI DI PLAYSTORE MENURUT PERSPEKTIF HAK CIPTA (TAXATION OF SONG WORKS THROUGH THE APPLICATION ON PLAYSTORE BY COPYRIGHT PERSPECTIVE)
}

\author{
Aditya Suud \\ Fakultas Hukum, Universitas Pembangunan Nasional "Veteran” Jakarta \\ Jl. RS. Fatmawati Raya, Pd. Labu, Kec. Cilandak, Kota Depok, Jawa Barat 12450 \\ e-mail: adityasuud@upnvj.ac.id \\ Suherman \\ Fakultas Hukum, Universitas Pembangunan Nasional "Veteran” Jakarta \\ Jl. RS. Fatmawati Raya, Pd. Labu, Kec. Cilandak, Kota Depok, Jawa Barat 12450 \\ e-mail: suherman upn@yahoo.com
}

\begin{abstract}
ABSTRAK
Penelitian ini bertujuan untuk mengetahui dan memahami bagaimana bentuk perlindungan hokum terhadap tersangka pada pembajakan hak cipta melalui aplikasi di Indonesia. Khususnya terhadap karya cipta digital program computer dalam bentuk bentuk aplikasi yang berisi dokumen elektronik berupa karya cipta lagu atau musik milik orang lain yang kemudian di publikasikan di salah satu aplikasi bernama Playstore. Penelitian ini menggunakan jenis penelitian Yuridis-Normatif dengan melakukan pendekatan peraturan perundang- undangan (statute approach) dan pendekatan konseptual (konseptual approach). Pengumpulan data dari bahan sekunder dilakukan dengan metode kepustakaan dan dianalisa menggunakan metode kualitatif dan melakukan analisis yuridis. Hasil penelitian ini adalah di Indonesia belum ada aturan khusus mengenai pembajakan lagu melalui media daring atau Internet digital maka UU No. 28 Tahun 2014 mengenai Hak Cipta dapat menjangkau hal tersebut dengan menggunakan dasar seperti yang telah dijelaskan diatas yaitu dapat dikaitkan dengan pasal 32 Jo.pasal 48 UU No. 19 Tahun 2016 mengenai Informasi Dan Transaksi Elektronik walaupun kejahatan yang dilakukan adalah mengenai pelanggaran hak orang lain yaitu Hak Cipta. Hal tersebut juga disebabkan oleh konsep yang belum tepat mengenai pengaturan pembajakan dalam media internet atau elektronik. Konsep yang diperlukan ini adalah dengan mendirikan badan baru yang menjembatani dua aturan yang berbeda maka hal ini akan menjadikan penanganan mengenai pelanggaran pembajakan melalui aplikasi Playstore akan lebih jelas kewenangan mengadili dari permasalahan tersebut.
\end{abstract}

Kata kunci: Hak cipta; Dokumen elektronik; Analisis yuridis; Media daring; Media elektronik 


\begin{abstract}
This study aims to find out and understand how the form of legal protection against suspects in copyright piracy through applications in Indonesia. Especially for digital computer program copyrights in the form of applications containing electronic documents in the form of songwriting or music belonging to other people which are then published in an application called Playstore. This study uses a juridical-normative research type by applying a statutory approach and a conceptual approach. Collecting data from secondary materials was carried out using literature methods and analyzed using qualitative methods. The result of this research is that in Indonesia there are no specific rules regarding pirating songs through online media or digital Internet. 28 of 2014 regarding Copyright can reach this by using the basis as described above, which can be linked to article 32 Jo. Article 48 of Law no. 19 of 2016 regarding Electronic Information and Transactions even though the crime committed was regarding the violation of the rights of others, namely Copyright. This is also due to the inaccurate concept of regulating piracy in internet or electronic media. The concept needed is to establish a new agency that bridges two different rules, so this will make handling of piracy violations through the Playstore application clearer in the authority to judge these problems.
\end{abstract}

Keywords : Copyright; Electronic documents; Juridical Analysis; digital media; Digital electronic 


\section{PENDAHULUAN}

\section{Latar Belakang Masalah}

Di era saat ini seiring dengan masuknya era industry 4.0 perkembangan teknologi akibat peningkatan pembangunan di Indonesia semakin pesat, Istilah Industri 4.0 sendiri secara resmi lahir di Jerman tepatnya saat diadakan Hannover Fair pada tahun 2011'. Hal ini dibuktikan dengan terjadinya perubahan terhadap cara memenuhi kebutuhan masyarakat, dimana sebelum masuknya era industry 4.0 masih bersifat analog dan hal tersebut berubah menjadi serba digital sampai saat ini, sehingga dalam perkembangan teknologi menjadikan teknologi informasi ini sebagai suatu trend.

Hal ini dapat terjadi tentu saja karena adanya internet, Internet diibaratkan seperti jaring laba-laba (the web) yang terdiri dari titik-titik (node) yang terhubung antara satu sama lainnya. Sehingga penggunaan internet sebagai teknologi informasi semakin mempermudan manusia dalam membagikan atau menggandakan suatu karya digital dengan mudah dan cepat.

Media digital adalah media yang dikodekan dalam format yang dapat dibaca mesin, termasuk program-program computer, video games, halaman web dan situs web, termasuk media social, dokumen elektronik, digital audio dan video, seperti mp3, mp4 dan e-buku adalah contoh media digital. Maka dari itu unsur unsur di dalam media digital itu sendiri memuat hak kekayaan intelektual, karena isi dari media digital itu pastilah sebuah hasil karya atau buah pikir dari manusia yang menimbulkan hak atas karya tersebut khususnya hak cipta.

Agar setiap karya cipta manusia yang terdiri dari ilmu pengetahuan, seni dan sastra lagu maupun kreasi yang tercipta dari seseorang tidak diklaim atau dibajak maka perlu untuk dilindungi. Perlindungan terhadap karya cipta di Indonesia diatur dengan Undang-Undang Nomor 28 Tahun 2014 tentang Hak Cipta, yang timbul secara otomatis berdasarkan prinsip deklaratif. Hak cipta dibuat dengan tujuan untuk melindungi hak ekonomi dan hak moral Pencipta dan pemilik Hak Terkait.

Berdasarkan sejarahnya, penamaan hak cipta berasal dari penyingkatan kata hak pencipta. Pengistilahan ini pertama kali dikemukakan pada Konferensi Budaya Bandung tahun 1952². Hak cipta sendiri termasuk bagian hukum benda dalam klasifikasi hukum perdata. Dalam hukum benda diatur mengenai hak kebendaan yang terbagi dalam benda immaterial ( Tidak berwujud ) dan benda materil ( Berwujud ). Hak benda atau material adalah hak absolut atas sesuatu benda berwujud, tetapi beberapa objek hak

${ }^{1}$ Prasetyo, Hoedi dan Wahyudi Sutopo, Industri 4.0: Telaah Klasifikasi Aspek Dan Arah Perkembangan Riset, Jurnal Teknik Industri, 13 (1): 18

2 Sardjono, Agus, Hak Cipta Bukan Hanya Copyright. Jurnal Hukum, 40 (2): 252 
absolut terdapat benda tak berwujud. Itulah yang disebut dengan nama Hak Kekayaan Intelektual. ${ }^{3}$

Namun dengan adanya kemajuan teknologi internet ternyata hal ini juga berdampak terhadap peningkatan pelanggaran Hak Cipta di Indonesia. Khususnya terhadap karya cipta digital program computer dalam bentuk bentuk aplikasi yang berisi dokumen elektronik berupa karya cipta lagu atau musik milik orang lain yang kemudian di publikasikan di salah satu aplikasi bernama Playstore.

Dampak negatif selain dari pembajakan yang ditimbulkan oleh kemajuan teknologi elektronik antara lain penggunaan alat perekam gambar yang canggih seperti audio dan video, yang dapat merekam lagu dan film orang lain tanpa izin dari pencipta atau pemilik hak cipta, dan bertujuan untuk mendapatkan keuntungan tanpa membayar pajak dan royalti kepada negara dan pencipta, sehingga bisa disebut pelanggaran hak cipta 4 .

Aplikasi Playstore merupakan aplikasi yang memungkinkan para pengguna layanan internet untuk dapat mendownload atau mengunduh aplikasi yang dikehendaki. PlayStore merupakan layanan digital yang didalamnya melingkupi toko daring seperti buku, film, games dan aplikasi lagu atau aplikasi lainnya. ${ }^{5}$

Karena Playstore adalah sebuah layanan digital yang didalamnya melingkupi toko daring maka seseorang programmer atau pemrogram dapat mengunggah aplikasi yang ia buat yang berisikan dukumen elektronik berupa karya lagu milik orang lain ke dalam aplikasi playstore dengan tujuan mengomersialkan aplikasinya. Karena kemudahan itulah dengan memanfaatkan peluang tersebut untuk mendapatkan keuntungan maka para programmer atau pemrogram berlomba lomba untuk membuat suatu aplikasi yang diminati oleh oranglain.

Pembuatan aplikasi yang berisi dokumen elektronik berupa karya cipta lagu milik orang lain tanpa adanya lisensi untuk kemudian diunggah ke aplikasi Playstore adalah sebuah hal yang dilarang dalam Undang-Undang Nomor 28 Tahun 2014 tentang Hak Cipta. yang mana hal tersebut termasuk dalam pelanggaran pembajakan karya milik orang lain. Pembajakan dalam arti luas adalah Penggandaan suatu Ciptaan dan atau produk Hak Terkait secara tidak sah yang mana pendistribusian barang hasil penggandaan bertujuan untuk memperoleh keuntungan ekonomi.

Namun dalam hal penggandaan yaitu proses, perbuatan, atau cara menggandakan satu salinan cipta lagu- lagu dalam bentuk dokumen elektronik yang kemudian dijadikan satu dalam sebuah aplikasi. Seorang

${ }^{3}$ Mahadi. 1985. Hak Milik Immateril, Jakarta: BPHN-Bina Cipta. Hlm 5-6

4 Dewi, Gusti Agung Putri Krisya dan I Wayan Novy Purwanto, Pelaksanaan Hukum Terhadap Pelanggaran Hak Cipta Di Bidang Pembajakan Sinematografi ( Film/Video). Kertha Semaya, 5 (1): 11-12

${ }^{5}$ Sulistiowati, Fany Nuranazmi, Usability Testing Aplikasi Playstore Menggunakan SmartPLS (Sub judul: kurnal informatika). jurnal Ilmu-ilmu Informatika dan Manajemen STMIK, 20 (10):1 
programmer atau pemrogram pastilah menggunakan perangkat elektronik terutama computer dalam melakukan hal tersebut. Yang mana kegiatan penggandaan dokumen elektronik tersebut melanggar Undang-Undang Nomor 19 Tahun 2016 tentang informasi dan transaksi elektronik.

Sebagaimana bunyi pasal 1 ayat 4 Undang-Undang Nomor 19 Tahun 2016 tentang informasi dan transaksi elektronik " Dokumen Elektronik adalah setiap Informasi Elektronik yang dibuat, diteruskan, dikirimkan, diterima, atau disimpan dalam bentuk analog, digital, elektromagnetik, optikal, atau sejenisnya, yang dapat dilihat, ditampilkan, dan/atau didengar melalui Komputer atau Sistem Elektronik, termasuk tetapi tidak terbatas pada tulisan, suara, gambar, peta, rancangan, foto atau sejenisnya, huruf, tanda, angka, Kode Akses, simbol atau perforasi yang memiliki makna atau arti atau dapat dipahami oleh orang yang mampu memahaminya. ".

Maka secara tidak langsung bahwa pelanggaran pembajakan hak cipta lagu juga melanggar Undang-Undang Nomor 19 Tahun 2016 tentang informasi dan transaksi elektronik. Oleh sebab itu perlu kiranya pengaturan yang lebih jelas mengenai hal tersebut yang harus mengacu kepada nilai-nilai dasar yang bersifat universal yaitu sustainability (keberlanjutan), unity (keutuhan), harmony (keserasian), equality (keseimbangan), equity (kepatutan). ${ }^{6}$ Berdasarkan hal tersebut di atas maka penulis tertarik dan menuangkan dalam penelitihan skripsi dengan judul " PEMBAJAKAN KARYA LAGU MELALUI APLIKASI DI PLAYSTORE MENURUT PERSPEKTIF HAK CIPTA".

\section{Rumusan Masalah}

Berdasarkan latar belakang yang telah penulis jabarkan diatas, maka penulis memiliki permasalahan yang akan diteliti dalam penelitian ini adalah sebagai berikut:

1. Bagaimana UUHC dapat menjangkau pembajakan yang dilakukan melalui media

digital?

2. Bagaimana konsep perlindungan hukum yang ideal terhadap kasus pembajakan karya lagu melalui aplikasi di playstore?

\section{METODE PENELITIAN}

Metode penelitian itu sendiri merupakan cara ilmiah guna mendapatkan data dengan tujuan dan kegunaan secara tertentu. Maka dari itu guna mencapai tujuan tersebut diperlukan suatu metode yang relevan

${ }^{6}$ Suherman dan Dwi Aryanti R, Yuliana Yuli W, Hak-Hak Personal Dalam Hukum Perdata Ekonomi Di Indonesia. Jurnal Yuridis, 1 (1):136 
dengan tujuan yang diinginkan. Didalam metode itu sendiri terdapat aspek aspek yang terdiri dari tahapan-tahapan kegiatan yang dilakukan, bahan, alat dan cara yang digunakan untuk mengumpulkan data, mengolah, serta menganalisa untuk memperoleh jawaban atas pertanyaan penelitian yang dilakukan?.

Adapun jenis penelitian ini yuridis normatif. Yuridis normatif dilakukan dengan cara menelaah dan meng interpretasikan hal-hal yang bersifat teoritis yang menyangkut asas, konsepsi, doktrin dan norma hukum. Menurut Ronny Hanitijo Soemitro pendekatan yuridis normatif adalah pendekatan kepustakaan yang berpedoman pada peraturan-peraturan, buku-buku atau literatur-literatur hukum serta bahan-bahan yang mempunyai hubungan permasalahan dan pembahasan dalam penulisan ini ${ }^{8}$. Penelitian ini menggunakan pendekatan Undangundang (statute Approach); Pendekatan Konseptual (Conceptual Approach).

Dan sumber Data yang diperlukan dalam penelitian yang hendak dilakukan penulis ini adalah data sekunder, yaitu data yang diperoleh dari dokumen-dokumen resmi, buku-buku yang berhubungan dengan objek penelitian, basil penelitian dalam bentuk laporan, skripsi, tesis dan peraturan perundang-undangan. Data sekunder ini dapat digolongkan menjadi 3 (tiga) karakteristik kekuatan mengikatnya, yaitu sebagai berikut:

a. Bahan hukum primer, yang dalam hal ini adalah Peraturan Perundang-Undangan dan putusan pengadilan yang terkait dengan penulisan skripsi ini, di antaranya adalah UndangUndang Republik Indonesia dan dokumen-dokumen lain yang dikeluarkan oleh badan-badan resmi pemerintah. Bahan hukum primer yang digunakan dalam penelitian ini adalah:

1) Undang-Undang Dasar Negara Republik Indonesia Tahun 1945;

2) Undang-Undang Nomor 28 Tahun 2014 tentang Hak Cipta

3) Undang-Undang Nomor 19 Tahun 2016 tentang Informasi Dan Transaksi Elektronik

4) Peraturan Bersama Menteri Hukum dan Hak Asasi Manusia Republik Indonesia Dan Menteri Komunikasi dan Informasi Republik Indonesia Nomor 14 Tahun 2015 Nomor 26 Tahun 2015 Tentang Pelaksanaan Penutupan Konten Dan/Atau Hak Akses Pengguna Pelanggaran Hak Cipta Dan/Atau Hak Terkait Dalam Sistem Elektronik

5) Putusan pengadilan Nomor 864/Pid.Sus?2019/PM JKT.SEL

${ }^{7}$ Soemitro. 1990. Metodologi Penelitian Hukum, Jakarta: Rineka Cipta. Hlm. 10

8 Soemitro, Ronny Hanitijo. 2001. Metodologi Penelitian Hukum dan Jurimetri, Jakarta: Ghalia Indonesia. Hlm. 10 
b. Bahan hukum sekunder, yaitu bahan hukum yang memberikan penjelasan mengenai bahan hukum primer, yang terdiri dari literatur-literatur, buku-buku yang berkaitan dengan teori keadilan hukum, Bahan hukum sekunder diperoleh dengan cara studi dokumen, mempelajari permasalahan dari bukubuku, literatur, makalah dan kamus hukum dan bahan-bahan lainnya yang berkaitan dengan materi ditambah lagi dengan kegiatan pencarian data menggunakan internet.

c. Bahan hukum hukum tersier, yaitu bahan hukum penunjang yang memberi petunjuk dan penjelasan terhadap bahan hukum primer dan bahan hukum sekunder, seperti kamus hukum dan kamus bahasa Indonesia yang dapat dipergunakan sebagai informasi bagi penelitian ini

Adapun cara Pengumpulan Data dan Teknik Analisis Data yang digunakan dalam penelitian ini dilakukan dengan Penelitian Kepustakaan (Library Research), yaitu suatu cara memperoleh data melalui penelitian kepustakaan, yang dalam penulisan laporan penelitian ini penulis mencari data dan keterangan-keterangan dengan membaca putusan pengadilan, buku-buku, bahan kuliah, hasil penelitian, dan berbagai peraturan perundang-undangan yang berkaitan yang diperlukan dalam penelitian ini.

Dan Teknik analisis merupakan langkah yang berkaitan dengan pengolahan data yang telah ditentukan baik berupa data primer maupun data sekunder yang telah dikumpulkan untuk menjawab rumusan masalah dengan cara analisis kualitatif. Sedangkan untuk menganalisa bahan hukum dilakukan dengan cara content analysis. Teknik penulisan deskriptif, yaitu menjelaskan secara rinci dan sistematis terhadap gambaran masalah dan menjelaskan dengan mnarasi untuk menggambarkan kejadian tersebut.

\section{PEMBAHASAN}

\section{Bagaimana UUHC dapat menjangkau pembajakan yang dilakukan melalui media digital ?}

Pada saat ini dunia atau masyarakat gelobal telah memasuki fase revolusi industry 4.0 dan tak terkecuali satupun. Revolusi itu sendiri memiliki makna sebagai perubahan besar terhadap cara manusia memproduksi barang. Era ini akan mendisrupsi berbagai aktivitas manusia dalam berbagai bidang, tidak hanya dalam bidang teknologi saja, namun juga bidang yang lain seperti ekonomi, sosial, dan politik 9 .

Dan kini perlahan tapi pasti semua hal beralih kearah digital, hal ini dibuktikan dengan kemudahan seseorang untuk memproduksi suatu karya

9 Prasetyo, Banu dan Umi Trisyanti, Revolusi Industri 4.0 Dan Tantangan Perubahan Sosial. IPTEK, 1 (5): 22 
yang dibuatnya dengan mudah padahal dahulu untuk memproduksi karya tersebut membutuhkan waktu yang lama dan sulit.

Karena kemudahan itulah maka hal ini menjadi salah satu faktor dari semakin banyaknya karya yang diciptakan oleh anak bangsa yang dibuat oleh dirinya sendiri dan juga dipublikasikan sendiri olehnya di media digital. Karena terdapat sebuah karya yang merupakan buah fikir dari seseorang, maka disana juga harus ada undang undang yang melindungi mengenai karya tersebut. Maka dari itu HKI ini sangat penting dalam kehidupan modern ini, dan selayaknyalah HKI tersebut untuk dilindungi ${ }^{10}$.

Dalam sejarahnya istilah hak cipta merupakan penyingkatan dari kata Hak Pencipta, sejarah ini bermula pada abad XV saat ditemukannya alat mesin cetak ${ }^{11}$. Hak Cipta di Indonesia saat ini diatur dalam UU No. 28 Tahun 2014 mengenai Hak Cipta. Pengaturan mengenai hak cipta ini di Indonesia telah ada sejak zaman penjajahan belanda yang dahulu diatur dalam Auteurswet 1912 dan mengalami pergantian dengan UU No. 6 Tahun 1982 dan kemudian digantikan menjadi UU No. 19 Tahun 2002 dan mengalami pergantian kembali dengan UU No. 28 Tahun 2014 Mengenai Hak Cipta hingga saat ini.

UU No. 28 tahun 2014 Mengenai Hak Cipta dalam penjelasannya secara umum huruf ( $\mathrm{j}$ ) menjelaskan tentang Penggunaan Hak Cipta dan Hak Terkait dalam sarana multimedia untuk merespon perkembangan teknologi informasi dan komunikasi. dan komunikasi. karena dalam perkembangan teknologi ini sangatlah pesat dan terus bertumbuh.

Hak cipta adalah hak eksklusif pencipta yang timbul secara otomatis berdasarkan prinsip deklaratif ${ }^{12}$. Yang berarti bahawa hak cipta ini memiliki suatu kekhususan daripada hak hak lain yang termasuk dalam HKI, perlindungan hak cipta ini timbul bukan karena pendaftarannya melainkan karena pengumuman pertama kali dan tidak diwajibkan untuk didaftarkan ${ }^{13}$.

Namun seiring dengan perkembangan teknologi tentunya juga berdampak terhadap bentuk bentuk pelanggaran atau kejahatan yang dilakukan akibat perkembangan teknologi. Sehingga menjadikan pendaftaran merupakan suatu kewajiban yang harus dilakukan apabila ingin mendapatkan perlindungan akan karya karya yang dibuat ${ }^{14}$.

10 Yanto, Oksidelfa, Konsep Perlindungan Hak Cipta Dalam Ranah Hukum Hak Kekayaan Intelektual (Studi Kritis Pembajakan Karya Cipta Musik dalam Bentuk VCD dan DVD. Yustisia, 4 (3):750

${ }^{11}$ Sardjono, Agus, Hak Cipta Bukan Hanya Copyright. Jurnal Hukum, 40 (2): 253

12 Muhammad, Abdulkadir. 2017. Kajian Hukum Ekonomi Hak Kekayaan Intelektual, Bandung: PT. Citra Aditya Bakti. Hlm. 157

13 Atsar, Abdul. 2018. Mengenal Lebih Dekat Hukum Hak Kekayaan Intelektual, Yogyakarta: CV Budi Utama. Hlm. 34

14 Kusno, Habi, Perlindungan Hukum Hak Cipta Terhadap Pencipta Lagu Yang Diunduh Melalui Internet. Fiat Justisia, 10 (3):492 
UUHC 2014 turut mengatur mengenai pelanggaran Hak Cipta yang dilakukan melalui media internet hal ini diatur dalam Pasal 54 UUHC yang pada intinya yaitu ${ }^{15}$ :

a. Melakukan pengawasan terhadap pembuatan serta penyebarluasan konten yang melanggar Hak cipta serta hak terkait

b. Melakukan kerjasama dan koordinasi dengan berbagai pihak dalam hal pencegahan pembuatan serta penyebarluasan konten yang melanggar Hak Cipta serta hak terkait

c. Melakukan pengawasan terhadap perbuatan perekaman di tempat pertunjukan

Namun pengaturan mengenai Pembajakan yang dilakukan melalui media internet masih sangatlah kurang, regulasi yang mengatur mengenai pembajakan melalui media internet masih belum jelas. Sehingga dibutuhkan pendapat hakim dalam memberikan putusan terhadap kasus ini. Hal ini dapat dilihat melalui Putusan Nomor 846/Pid.Sus/2019/PN JKT.SEL.

Aturan mengenai pembajakan saat ini diatur dalam UU No. 28 tahun 2014 tentang hak cipta dalam pasal $113,116,117,118$. Namun dalam aturan aturan tersebut belum ada yang mengatur mengenai pembajakan melalui media internet. Adapun Pendapat hakim yang dapat dikenakan mengenai hal tersebut dapat dilihat dalam putusan Nomor 846/Pid.Sus/2019/PN JKT.SEL adalah sebagai berikut.

Mengenai pembajakan yang diatur dalam UU No. 28 tahun 2014 tentang hak cipta dalam pasal $113,116,117,118$. Dalam pasal pasal tersebut melindungi hak ekonomi dan hak moral, dimana pencipta atau pemegang hak terkait berhak atas karya yang dimilikinya, namun apabila terdapat pihak lain yang tiba tiba mengambil atau menggunakan karyanya tersebut tanpa izin hal itu jelas melanggar hak yang dimiliki oleh pencipta atau pemegang hak terkait.

Dalam pembuatan aplikasi yang berisi dokumen elektronik berupa karya cipta lagu milik orang lain tanpa adanya lisensi untuk kemudian diunggah ke aplikasi Playstore adalah sebuah hal yang dapat dikategorikan sebagai pembajakan. Pembajakan dalam arti luas adalah Penggandaan suatu Ciptaan dan atau produk Hak Terkait secara tidak sah yang mana pendistribusian barang hasil penggandaan bertujuan untuk memperoleh keuntungan ekonomi.

Namun dalam hal penggandaan yaitu proses, perbuatan, atau cara menggandakan satu salinan cipta lagu- lagu dalam bentuk dokumen elektronik yang kemudian dijadikan satu dalam sebuah aplikasi. Seorang programmer atau pemrogram pastilah menggunakan perangkat elektronik terutama computer dalam melakukan hal tersebut. Yang mana kegiatan penggandaan dokumen elektronik tersebut melanggar Undang-Undang Nomor 19 Tahun 2016 tentang informasi dan transaksi elektronik.

\footnotetext{
15 Undang-Undang No. 28 Tahun 2014 Tentang Hak Cipta
} 
Sebagaimana bunyi pasal 1 ayat 4 Undang-Undang Nomor 19 Tahun 2016 tentang informasi dan transaksi elektronik " Dokumen Elektronik adalah setiap Informasi Elektronik yang dibuat, diteruskan, dikirimkan, diterima, atau disimpan dalam bentuk analog, digital, elektromagnetik, optikal, atau sejenisnya, yang dapat dilihat, ditampilkan, dan/atau didengar melalui Komputer atau Sistem Elektronik, termasuk tetapi tidak terbatas pada tulisan, suara, gambar, peta, rancangan, foto atau sejenisnya, huruf, tanda, angka, Kode Akses, simbol atau perforasi yang memiliki makna atau arti atau dapat dipahami oleh orang yang mampu memahaminya. “. Maka secara tidak langsung bahwa pelanggaran pembajakan hak cipta lagu juga melanggar Undang-Undang Nomor 19 Tahun 2016 tentang informasi dan transaksi elektronik jika melihat dari perbuatnnya.

Dimana dalam UU ITE tidak diatur mengenai pembajakan Hak Cipta, namun dalam hal penggandaan yaitu proses, perbuatan, atau cara menggandakan atau memindahkan atau mentransfer satu salinan dalam bentuk dokumen elektronik diatur dalam pasal 32 UU No. 19 Tahun 2016 tentang Informasi Dan Transaksi Elektronik. Yang mana dalam pasal tersebut diatur mengenai perbuatan seseorang yang dilakukan dengan sengaja dan tidak memiliki hak untuk mengubah, menambah, memindahkan atau melakukan transmisi suatu dokumen elektronik milik orang lain.

Sehingga dalam putusan Nomor 846/Pid.Sus/2019/PN JKT.SEL hakim menyamakan pembajakan ini sama dengan perbuatan atau cara menggandakan atau memindahkan atau mentransfer satu salinan dalam bentuk dokumen elektronik. Sebagaimana yang diatur dalam pasal 32 UU No. 19 Tahun 2016 tentang Informasi Dan Transaksi Elektronik. Maka UU No. 28 Tahun 2014 dapat menjangkau pembajakan yang dilakukan melalui media Internet atau daring.

Dari uraian ketentuan hukum di atas mengenai bagaimana UU No 28 Tahun 2014 Tentang Hak Cipta dapat menjangkau pembajakan yang dilakukan melalui media digital daring atau internet, pelaku pembajakan menggunakan media digital daring atau internet tersebut dapat dikenakan pasal pasal 32 Jo.pasal 48 UU No. 19 Tahun 2016 tentang Informasi Dan Transaksi Elektronik. Karena unsur dalam pasal 32 Jo.pasal 48 UU ITE tersebut terpenuhi, dimana ketika seseorang melakukan pembajakan karya cipta lagu milik oranglain sebagaimana yang diatur dan ditetapkan dalam pasal 113, 116, 117, 118. UU No 28 Tahun 2014 Tentang Hak Cipta, seseorang yang melakukan pembajakan tersebut pastilah menggunakan perangkat elektronik untuk kemudian mengubah, menambah, memindahkan atau melakukan transmisi suatu karya cipta lagu milik orang lain dalam bentuk dokumen elektronik.

Mengingat di Indonesia belum ada aturan khusus mengenai pembajakan lagu melalui media daring atau Internet digital maka UU No.28 Tahun 2014 mengenai Hak Cipta dapat menjangkau hal ini dengan menggunakan dasar seperti yang telah dijelaskan diatas yaitu dapat dikaitkan dengan pasal 32 Jo.pasal 48 UU No. 19 Tahun 2016 mengenai Informasi Dan Transaksi 
Elektronik. Walaupun dalam hal ini pembajakan jelas merupakan wewenang atau ranah dari UU No. 28 Tahun 2014 mengenai Hak Cipta.

\section{Bagaimana konsep perlindungan hukum yang ideal terhadap kasus pembajakan karya lagu melalui aplikasi di playstore ?}

Pada masa ini Intellectual property Rights atau Hak Kekayaan Intelektual (HKI) memegang peran penting dalam aspek kehidupan. Hal ini dapat terjadi karena HKI berkaitan erat dengan teknologi, ekonomi, maupun seni budaya. Maka dari itu HKI ini sangat penting dalam kehidupan modern ini, dan selayaknyalah HKI tersebut untuk dilindungi. ${ }^{16}$ Salah satu dari HKI tersebut adalah Hak Cipta.

Hak atas karya cipta adalah salah satu bagian dari HKI yang dilindungi oleh Negara, yang didalamnya terdiri atas hak ekonomi (economic rights) dan hak moral (moral rights). Dimana hak ekonomi merupakan hak untuk mendapatkan manfaat ekonomi atas ciptaan serta produk hak terkait. Dan hak moral adalah hak yang melekat pada diri pencipta atau pemegang hak yang tidak dapat dihilangkan atau dihapus tanpa alasan apapun, walaupun Hak Cipta atau Hak Terkait telah dialihkan. ${ }^{17}$

Moderenisasi ini tentu menyebabkan perubahan besar dalam kehidupan manusia dari berbagai aspek. Teknologi informasi adalah aspek paling besar yang mengalami perubahan pada dzaman modern kini. Dimana orang lain dapat mengunduh atau mengunggah suatu hal yan ia kehendaki dalam bentuk digital, dengan tujuan agar dapat dilihat oleh orang lain atau untuk dijadikan komoditi bagi seseorang karna berbentuk dan bernilai.

Tentunya hal ini sangat berbahaya bagi pencipta atau pemegang hak terkait, karena media digital adalah media yang dikodekan dalam format yang dapat dibaca oleh mesin yang didalamnya meliputi program-program computer, video games, halaman web dan situs web, termasuk media social, dokumen elektronik, digital audio dan video, seperti mp3, mp4 dan e-buku adalah contoh media digital. Maka dari itu unsur unsur di dalam media digital itu sendiri memuat hak kekayaan intelektual, karena isi dari media digital itu pastilah sebuah hasil karya atau buah pikir dari manusia yang menimbulkan hak atas karya tersebut khususnya hak cipta.

Hal tersebut terlihat melalui survei yang dilakukan oleh International Federation of Phonographic Industry (IFPI) yang merupakan organisasi industri rekaman dunia. Survei berjudul "Music Listening 2019" pada 24 September 2019 lalu menunjukkan 89\% responden mengaku mendengarkan musik melalui layanan streaming on-demand. Data tersebut berasal dari 21 negara yang dengan mengambil sampel yang berusia antara 16 dan 64 tahun.

16 Yanto, Oksidelfa, Konsep Perlindungan Hak Cipta Dalam Ranah Hukum Hak Kekayaan Intelektual (Studi Kritis Pembajakan Karya Cipta Musik dalam Bentuk VCD dan DVD). Yustisia, 4 (3): 750

17 Djaja, Ermansyah. 2009. Hukum Hak Kekayaan Intelektual, Jakarta: Sinar Grafika. Hlm.115 
Hal ini menunjukkan bahwa kebanyakan orang sekarang mendengarkan musik melalui layanan streaming. Hal ini jelas membuktikan bahwa kemajuan dari teknologi informasi telah merubah kebiasaan masyarakat, masyarakat Indonesia khususnya.

Namun dengan adanya kemajuan teknologi ternyata hal ini juga berdampak terhadap peningkatan pelanggaran Hak Cipta di Indonesia. Kejahatan di bidang hak cipta, oleh Marc Ancel dikatakan sebagai masalah kemanusiaan dan masalah sosial. ${ }^{18}$ Pelanggaran terhadap hak cipta milik orang lain yang meningkat karena adanya kemajuan teknologi ini adalah pembajakan.

Dimana pembajakan ini adalah kegiatan yang dilakukan dengan melakukan penggandaan ciptaan milik orang lain atau produk hak terkait secara tidak sah serta melakukan pendistribusian barang hasil penggandaan secara luas dengan maksud untuk memperoleh keuntungan ekonomi untuk dirinya pribadi. Karena dengan mudahnya seseorang dapat menggandakan karya lagu milik orang lain dalam bentuk dokumen elektronik. Hal ini jelas merugikan pencipta dan pemegang hak terkait.

Bukti lain dari meningkatnya kemajuan teknologi itu sendiri adalah dengan munculnya aplikasi playstore. Aplikasi Playstore merupakan aplikasi yang memungkinkan para pengguna layanan internet untuk dapat mendownload atau mengunduh aplikasi yang dikehendaki. PlayStore merupakan layanan digital yang didalamnya melingkupi toko daring seperti buku, film, games dan aplikasi lagu atau aplikasi lainnya. ${ }^{19}$

Dapat dilihat dalam aplikasi ini banyak terjadi pembajakan lagu milik orang lain dengan cara mengunggah aplikasi yang berisikan lagu lagu milik orang lain tanpa izin. Dan ketika seseorang mengunduh aplikasi yang berisikan lagu milik orang lain tersebut maka pemilik alikasi tersebut akan mendapat keuntungan ekonomi bagi dirinya sendiri. Sedangkan Hak ekonomi adalah hak eksklusif yang didapatkan pencipta atau pemegang hak Karya Cipta guna memperoleh manfaat ekonomi. Pencipta atau Pemilik hak cipta memiliki hak ekonomi dalam hal ${ }^{20}$ :

a. penerbitan ciptaan;

b. penggandaan ciptaan dalam segala bentuknya;

c. penerjemahan ciptaan;

d. pengadaptasian, pengaransemenan, atau pentransformasian ciptaan;

e. pendistribusian ciptaan atau salinannya;

f. pertunjukan ciptaan;

\footnotetext{
18 Muladi, Bardan Nawawi Arief. 1984. Teori teori dan Kebijakan Pidana, Bandung: Alumni. HIm. 148

${ }^{19}$ Sulistiowati, Fany Nuranazmi, Usability Testing Aplikasi Playstore Menggunakan SmartPLS (Sub judul: kurnal informatika). jurnal Ilmu-ilmu Informatika dan Manajemen STMIK, 20 (10): 1

20 Sudjana, Pembatasan Perlindungan Kekayaan Intelektual (hak cipta)

Dalam Perspektif Hak Asasi Manusia. Jurnal Penelitian HAM, 10 (1): 74
} 
g. pengumuman ciptaan;

h. komunikasi ciptaan; dan

i. penyewaan ciptaan.

Hal ini tentulah sebuah pelanggaran, dimana seseorang telah melakukan pembajakan karya lagu milik seseorang dalam aplikasi digital digital. Dimana mengenai hak cipta ini diatur dalam Undang Undang No. 28 tahun 2014 mengenai hak cipta. Undang undang ini mengatur mengenai pembajakan, sedangkan mengenai perbuatan yang dilakukan dalam pembajakan ini diatur dalam Undang Undang No 19 tahun 2016 Tentang Informasi Dan Transaksi Elektronik.

Dimana dalam kegiatan pembajakan lagu milik orang lain melalui aplikasi Playstore ini pastilah dilakukan pembajakan secara digital. Dalam hal pembajakannya ini dilakukan dengan menggandakan karya lagu milik orang lain dalam bentuk dokumen elektronik untuk kemudian di unggah dalam bentuk aplikasi dalam aplikasi Playstore dengan tujuan untuk mendapatkan keuntungan bagi dirinya sendiri. Hal ini jelas melanggar Undang Undang No 19 tahun 2016 Tentang Informasi Dan Transaksi Elektronik. Dimana mengenai dokumen elektronik diatur dalam undang undang tersebut.

Dengan kemungkinan mudahnya pelanggaran hak cipta terjadi, penegakann hukum menghadapi tantangan yang tidak kecil. Dapat dikatakan pelanggaran hak cipta lebih cepat terjadi dan dapat bersifat masif ketimbang upaya pencegahan maupun penegakan hukum atasnya ${ }^{21}$. Oleh karena itu, setidaknya diperlukan kerja sama antara Direktur Jenderal Kekayaan Intelektual Kementerian Hukum dan Hak Asasi Manusia, dan Kementerian Komunikasi dan Informasi Republik Indonesia dalam mengatasi masalah pembajakan hak cipta musik di bidang digital atau online.. Karena pembajakan hak cipta di bidang online juga melibatkan pengawasan lintas sectoral, karena terhadap Internet itu sendiri, pengawasan ini menjadi wewenang milik Kementerian Komunikasi dan Informasi Republik Indonesia...22

Upaya penanggulangan kejahatan pembajakan karya musik tidak bisa diselesaikan sebagian, melainkan harus komprehensif, terkoordinasi dan terintegrasi. ${ }^{23}$ Menurut penulis konsep yang baik untuk dapat diterapkan bagi perlindunganyang ideal terhadap kasus pembajakan karya lagu melalui aplikasi playstore dapat dilakukan dengan mendirikan badan baru yang mengatur mengenai pembajakan karya music melalui media digital. Karena seperti apa yang telah disebut kan diatas bahwa terdapat aturan mengenai

21 Nugrahani, Rr Aline Gratika Pelanggaran Hak Cipta Sebagai Dampak Perkembangan Teknologi. Jurnal Hukum Pidana Dan Pembangunan Hukum Trisakti Vol, 1 (1): 4

22 https://ambadar.co.id/news/strategi-penanggulangan-pembajakan-musik-diranah-dunia-maya/, di akses pada tanggal 9 November 2020 pukul 23.45

23 Yanto, Oksidelfa, Konsep Perlindungan Hak Cipta Dalam Ranah Hukum Hak Kekayaan Intelektual (Studi Kritis Pembajakan Karya Cipta Musik dalam Bentuk VCD dan DVD). Yustisia, 4 (3): 755 
pembajakan sedangkan aturan tersebut belum menjelaskan secara jelas mengenai perbuatan yang dimaksudkan, dan dalam undang undang transaksi elektronik atau UU ITE diatur mengenai pelarangan penggandaan dokumen elektronik.

Perlunya didirikan badan yang khusus mengenai perlindungan HKI hak cipta khususnya dalam media digital karena upaya upaya yang dilakukan sebelumnya belum berhasil hal ini dapat dilihat diantaranya dengan melakukan berbagai revisi atas UndangUndang Hak Cipta. Bahkan delik UU hak cipta thn 1982 yang memiliki delik biasa diubah menjadi delik aduan pada UU No. 28 thn 2014 mengenai hak cipta. Namun semua itu belum sepenuhnya optimal.

Pendirian badan tersebut tidak dapat dilakukan sembarangan. Dimana badan tersebut dibutuhkan untuk dapat berfungsi dengan jangkauan yang lebih luas. Badan tersebut diharapkan dapat melakukan penangkapan, penyelidikan, penyidikan, bahkan penahanan kepada pelaku pembajakan mengingat pembajakan ini melibatkan pelangggaran lintas sektoral. Dengan dilakukannya pendirian badan tersebut merupakan salah satu cara untuk menanggulangi pembajakan yang terjadi dalam media digital khususnya dalam Playstore.

Dengan mendirikan badan baru yang menjembatani dua aturan yang berbeda maka hal ini akan menjadikan penanganan mengenai pelanggaran pembajakan melalui aplikasi Playstore akan lebih jelas kewenangan mengadili dari permasalahan tersebut.menurut penulis inilah konsep yang ideal yang harus segera dilakukan guna menangani pembajakan karya cipta lagu milik orang lain yang karyanya dijadikan komoditi oleh orang lain tanpa ada izin terlebih dahulu di aplikasi Playstore atau dengan kata lain perlindungan dari pembajakan di aplikasi Playstore.

\section{PENUTUP}

\section{Kesimpulan}

Indonesia telah memiliki peraturan mengenai Hak Cipta yang merupakan salah satu HKI yang dilindungi oleh Negara, dan diatur dalam Undang Undang No. 28 tahun 2014 mengenai hak cipta. Undang undang ini mengatur mengenai pembajakan secara konvensional namun mengenai pembajakan melalui media daring atau digital internet belum diatur secara jelas maka dari itu mengenai perbuatan yang dilakukan dalam pembajakan melalui aplikasi Playstore ini hanya dapat dikaitkan dengan Undang Undang No 19 tahun 2016 Tentang Informasi Dan Transaksi Elektronik.

Dimana pengenaan tersebut hanya berlandaskan dengan kegiatan pembajakan lagu milik orang lain melalui aplikasi Playstore ini dianggap dilakukan dengan menggandakan karya lagu milik orang lain dalam bentuk dokumen elektronik untuk kemudian di unggah dalam bentuk aplikasi dalam 
aplikasi Playstore dengan tujuan untuk mendapatkan keuntungan bagi dirinya sendiri. Yang mana mengenai dokumen elektronik diatur dalam Undang Undang No 19 tahun 2016 Tentang Informasi Dan Transaksi Elektronik sehingga dianggap melanggar hal tersebut.

UU No. 28 Tahun 2014 tentang hak cipta belum secara nyata dapat melindungi hak-hak pencipta dalam aplikasi playstore yang berada dalam media daring atau internet sehingga mengakibatkan pembajakan pembajakan yang berkembang dan merugikan pencipta maupun pemegang hak terkait, dan dalam mewujudkan perlindungan yang baik jelas dibutuhkan konsep perlindungan yang tepat dengan membuat suatu badan yang dapat menangani permasalahan lintas sectoral ini.

\section{Saran}

Pemerintah dalam hal ini Lembaga legislatif hendaknya menata kembali peraturan perundang-undangan atau regulasi yang berkenaaan dengan hak kekayaan intelek tual khususnya hak cipta diharapkan dalam penataan kembali ini dengan meninjau kembali dan melibatkan Direktur Jenderal Kekayaan Intelektual Kementerian Hukum dan Hak Asasi Manusia, dan Kementerian Komunikasi dan Informasi Republik Indonesia dalam mengatasi masalah pembajakan hak cipta musik di bidang digital atau online guna mendapatkan suatu konsep perlindungan hukum yang jelas mengingat undang undang hak cipta yang ada belum cukup memadai.

Mengingat peraturan yang baik adalah peraturan yang tidakhanya dapat mengatur dan memberikan hukuman, namun juga dapat memberikan efek pencegahan seterusnya. Dan pencipta atau pemegang hak terkait sebagai pemilik hak hak yang dimilikinya atas buah karyanya juga harus sadar akan hak haknya sehingga tidak membiarkan pelaku pembajakan ini bertindak sembarangan dengan menggunakan karya oranglain untuk kebutuhannya sendiri.

\section{DAFTAR PUSTAKA}

\section{Buku:}

Atsar Abdul (2018). Mengenal Lebih Dekat Hukum Hak Kekayaan Intelektual. Yogyakarta: CV Budi Utama.

Ermansyah Djaja (2009). Hukum Hak Kekayaan Intelektual. Jakarta: Sinar Grafika.

Hyronimus Rhiti (2015). Filsafat Hukum Edisi Lengkap (Dari Klasik ke Postmodernisme), Ctk. Kelima. Yogyakarta: Universitas Atma Jaya. 
Lili Rasjidi dan B. Arief Sidharta (1994). Filsafat Hukum Madzab dan Refleksi. Bandung: PT. Remaja Rosda Karya.

Mahadi (1985). Hak Milik Immateril. Jakarta : BPHN-Bina Cipta.

Muladi, Bardan Nawawi Arief (1984), Teori teori dan Kebijakan Pidana. Bandung: Alumni.

Peter Mahmud Marzuki (2016). Penelitian Hukum. Jakarta: Kencana Prenada Media Group.

Philipus M. Hadjon (1987). Perlindungan Rakyat Bagi Rakyat di Indonesia (sebuah Studi tentang Prinsip-Prinsipnya, Penanganannya oleh Pengadilan dalam Lingkungan Peradilan Umum dan Pembentukan Peradilan Administrasi Negara. Surabaya: PT. Bina Ilmu.

Ronny Hanitijo Soemitro (2001). Metodologi Penelitian Hukum dan Jurimetri. Jakarta:Ghalia Indonesia.

Suherman, Ade Maman (2002). Aspek Hukum Dalam Teknologi. Jakarta: Ghalia Indonesia.

Syamsul Hadi (2008). Panduan Berinternet Bagi Pemula. Surabaya : Tiara Aksa.

Soemitro (1990). Metodologi Penelitian Hukum. Jakarta: Rineka Cipta.

\section{Jurnal:}

Agus Sardjono (2010). Hak Cipta Bukan Hanya Copyright. Jurnal Hukum, 40 (2).

Fany Nuranazmi Sulistiowati (2019). Usability Testing Aplikasi Playstore Menggunakan SmartPLS (Sub judul: kurnal informatika). jurnal Ilmuilmu Informatika dan Manajemen STMIK, 20 (10).

Gusti Agung Putri Krisya Dewi dan I Wayan Novy Purwanto (2017). Pelaksanaan Hukum Terhadap Pelanggaran Hak Cipta Di Bidang Pembajakan Sinematografi ( Film/Video) Kertha Semaya, 5 (1).

Habi Kusno (2016). Perlindungan Hukum Hak Cipta Terhadap Pencipta Lagu Yang Diunduh Melalui Internet. Fiat Justisia, 10 (3).

Hoedi Prasetyo dan Wahyudi Sutopo (2018). Industri 4.0: Telaah Klasifikasi Aspek Dan Arah Perkembangan Riset. Jurnal Teknik Industri, 13 (1).

Oksidelfa Yanto (2015). Konsep Perlindungan Hak Cipta Dalam Ranah Hukum Hak Kekayaan Intelektual (Studi Kritis Pembajakan Karya Cipta Musik dalam Bentuk VCD dan DVD). Yustisia, 4 (3). 
Rr Aline Gratika Nugrahani (2018). Pelanggaran Hak Cipta Sebagai Dampak Perkembangan Teknologi. Jurnal Hukum Pidana Dan Pembangunan Hukum Trisakti, 1(1).

Suherman dan Dwi Aryanti R, Yuliana Yuli W (2014). Hak-Hak Personal Dalam Hukum Perdata Ekonomi Di Indonesia. Jurnal Yuridis, 1 (1).

Sudjana (2019). Pembatasan Perlindungan Kekayaan Intelektual (hak cipta) Dalam Perspektif Hak Asasi Manusia. Jurnal Penelitian HAM, 10 (1).

\section{Peraturan Perundang-Undang:}

Kitab Undang-Undang Hukum Perdata.

Republik Indonesia, Undang-Undang Dasar 1945

Republik Indonesia, Undang-Undang Hak Cipta, Undang-Undang Nomor 28 tahun 2014 Lembaran Negara Republik Indonesia Tahun 2014 Nomor 266, Tambahan Lembaran Negara Republik Indonesia Nomor 5599.

Republik Indonesia, Informasi Dan Transaksi Elektronik, Undang-Undang Nomor 19 Tahun 2016

\section{Sumber Lain:}

Agus, Candra Suratmaja, Am Badar \& Partners ,19 Juni 2013, ( https://ambadar.co.id/news/strategi-penanggulangan-pembajakanmusik-di-ranah-dunia-maya/), diakses pada 9 November 2020

Putusan Nomor 846/Pid.Sus/2019/PN JKT.SEL

Tesis hukum, "Pengertian Perlindungan Hukum Menurut Para Ahli," http://tesishukum.com/pengertianperlindungan-hukum-menurutpara-ahli/, diakses tanggal 28 oktober 2020

Tim redaksi, IFPI, diakses pada 9 November 2020 ( https://www.ifpi.org/wp-content/uploads/2020/07/MusicListening-2019-1.pdf) 